\title{
Fragmentering og disharmoni, eller helse og livsmestring?
}

\author{
Av Guro Hansen Helskog \\ Førstelektor i pedagogikk, Universitetet i Sørøst-Norge E-post:Guro.Helskog@usn.no
}

Folkehelse og livsmestring er innført som et nytt tverrfaglig emne i skolen. I dette essayet argumenteres det for at så lenge trekk ved eksisterende skolekultur fremmer det motsatte, er det ikke nok å innføre et nytt faglig emne. I essayet pekes det på enkelte slike trekk. Det argumenteres for at det må langt mer dyptgripende skolekulturelle endringer til dersom barn og unge skal få rom til å utvikle seg og dannes på måter som faktisk kan legge grunnlaget for god fysisk og psykisk helse og livsmestring, også i et livsløpsperspektiv.

Som lærer i norsk lærerutdanning har jeg stadig minnet meg selv og studentene mine på at det er barn og unge mennesker med sitt eget indre liv og individuelle sinn fylt av tanker, følelser og drømmer vi snakker om når vi bruker begrepet «elev». Av og til har jeg lest libanesiske Khalil Gibrans tekst om barn for studentene mine (1994/1923). Idet jeg har satt studentene i gang med å reflektere over innsikten teksten formidler, gjerne i par eller små grupper, har jeg også bedt dem forestille seg at det er staten eller skolen teksten snakker om. Etter at det moderne utdanningssystemet fra midten av 1800-tallet i økende grad vokste fram som et supplement til hjemmet når det gjaldt ansvaret for opplæringen og oppdragelsen av barn og unge i Norge, har nemlig også statens rolle som en slags «overforelder» bredt om seg, på godt og mindre godt. Teksten lyder som følger:

Og han sa:

Deres barn er ikke deres barn.

De er Livets sønner og døtre med egne lengsler.

De kommer gjennom dere, men ikke fra dere.

og selv om de er sammen med dere, tilhører de dere ikke.

Dere kan gi dem deres kjærlighet, men ikke deres tanker.

For de har egne tanker.

Dere kan gi hus til deres kropper, men ikke deres sjeler.

For deres sjeler bor i morgendagens hus, som dere ikke kan besøke, selv ikke i deres drømmer.

Prismet - IKO-Forlaget 2019

Tilgjengelig på https://journals.uio.no/index.php/prismet Publisert under CC BY-NC 4.o.

Årgang 70, hefte 1, s. 53-61

ISSN: 0032-8847, ISSN online:2535-311x 
Dere kan strebe etter å ligne dem, men prøv ikke å få dem til å ligne dere.

For livet går ikke bakover eller dveler ved $i$ går.

Dere er de buer som deres barn blir skutt ut fra som levende piler.

Bueskytteren ser merket på evighetens sti, og Han bøyer deg med sin kraft,

så Hans piler skal fly langt og fort.

Var glad over å bøyes i bueskytterens hånd.

For slik som Han elsker pilene som flyr, elsker Han også den trygge buen.

Khalil Gibran (1994/1923).

Idet disse refleksjonene skrives, pågår nok en omfattende reform av den norske grunnopplæringen, fra 1. klasse i barneskolen til fullført videregående opplæring, med ny Overordnet del av læreplanverket. Her heter det blant annet at folkehelse og livsmestring som tverrfaglig tema i skolen skal gi elevene «kompetanse som fremmer god psykisk og fysisk helse, og som gir muligheter til å ta ansvarlige livsvalg. (...). Videre skal temaet «bidra til at elevene lærer å håndtere medgang og motgang, og personlige og praktiske utfordringer på en best mulig måte». Aktuelle områder innenfor temaet hevdes å være «verdivalg og betydningen av mening i livet, mellommenneskelige relasjoner, å kunne sette grenser og respektere andres, og å kunne håndtere tanker, følelser og relasjoner».

Dette handler i stor grad om å legge til rette for at barn og unge kan få næret sitt indre liv, og med det evnen til å handle godt og ta gode valg, til beste for seg selv og andre, er mitt argument i denne teksten. Det er i det indre livet at nøkkelen til både helse og livsmestring hos individet ligger - også på folkehelseområder som dreier seg om alt fra hygiene, sunt kosthold og sunne relasjoner til rus for å forebygge epidemier og livsstilsrelaterte sykdommer, og på livsmestringsområder som dreier seg om alt fra å holde styr på privatøkonomi til å pleie relasjoner og utvikle psykisk motstandsdyktighet. Hvordan? Det er det jeg reflekterer over i denne teksten. I refleksjonen fors $\emptyset$ ker jeg å synliggjøre noen mønstre og sammenhenger som har betydning for helse og livsmestring ikke bare for barn og unge i skolen, men også for lærerne. Det sagt: «Skolevirkeligheten» og måtene den erfares på av dem som befolker denne virkeligheten, er langt mer kompleks, variert og sammensatt enn noen tekst vil kunne få fram.

\section{Tidens utdanningsparadigme}

Det utdanningsparadigmet jeg og mine studenter har virket i de siste årene, har lenge vært dominert av New public managementideologien som inntok den norske staten og utdanningssektoren fra og med slutten av 80- og begynnelsen av 90-tallet. Innenfor dette paradigmet vokste det fram en tiltakende ytregj $\emptyset$ ring av pedagogikken og menneskelivet, der begreper og ideer fra næringsliv og administrativ tenkning og språkbruk i økende grad invaderte skolens peda- 
gogiske tenkning - og praksis - generelt og i alle fag. Det har vært som om elevene i denne diskursen ikke lenger ble betraktet som unge mennesker med sine egne lengsler og mål. Snarere ble de innsatsfaktorer i statens politikk for fortsatt økonomisk vekst. Paradigmet har også bidratt til å gjøre barn og unge til brikker i diverse nasjonale og internasjonale konkurranser, der målet er å bli best i klassen sammenliknet med andre: Beste skole, beste kommune, beste fylkeskommune eller beste land. Det er nok å nevne nasjonale prøver og PISA-testene, med de uheldige konsekvensene overdrevent fokus på vurdering har ført med seg. Paradigmet har gitt seg til dels absurde utslag, både for elevers og læreres helse, og for alle fag, også fag man skulle tro kunne ta lettere på det enn de såkalt store skriftlige fagene. Så som i faget mat og helse, der eksemplet jeg vil bruke videre i essayet er hentet fra. Eksemplet er basert i et autentisk, men lett omskrevet og nøye anonymisert hjertesukk fra en mor og hennes barn. Blant annet velger jeg å omtale barnet som Eleven, og mat- og helselæreren som Læreren. Eksemplet er brukt med tillatelse fra mor og barn.

\section{BLINDET AV LEREPLANVERK OG VURDERINGSFORSKRIFT?}

Fra hun var ganske liten hadde Eleven elsket å bake, og etter hvert å lage mat. Hun hadde tidlig prøvd ut nye oppskrifter på familiens kjøkken i leiligheten i en av Norges største byer. Hun hadde derfor gledet seg veldig til å begynne i 9 . klasse. Lenge likte hun mat- og helsetimene, og hun fikk mye skryt av læreren. Men en dag hadde hun vært fortvilet da hun kom hjem etter ukens mat- og helseøkt. De hadde laget ostehorn den dagen, men akkurat idet Læreren gikk forbi, hadde Eleven gjort en feil. Læreren hadde sett det, og Eleven var sikker på at det kom til å gå ut over vurderingen av henne denne $\emptyset \mathrm{kten}$. Hva om det fikk konsekvenser for avgangskarakteren hennes? Moren var like fortvilet. Hun opplevde at alt fokuset på prestasjonsvurderinger i form av så vel tilsynelatende uformelle observasjonsvurderinger som formelle prøver og tester truet med a ta fra barnet hennes, ikke bare gleden over å bake og å lage mat, men også nysgjerrigheten og lærelysten $\mathrm{i}$ andre fag som var underlagt de samme rigide kulturmønstrene. Den tidligere nysgjerrige og våkne jenta var i ferd med å miste motivasjonen, til tross for sin relative skoleflinkhet. Moren opplevde at tenåringen hennes var konstant stresset. Til tross for at barnet trivdes på skolen og hadde det fint både med lærere og medelever, gikk sider av skolelivet ut over barnets livskvalitet. Mat- og helsetimene, som kunne vært et pusterom, var intet unntak.

Mat- og helselæreren var nemlig svært pliktoppfyllende med vurderingsarbeidet. Hun hadde lagt mye arbeid ned i å fortolke læreplanmålene, utvikle undervisningsopplegg i samsvar med disse, og plassere komponentene sirlig inn i skjemaer for lav, middels og høy måloppnåelse. I løpet av $\emptyset$ ktene passet hun på 
å observere hver enkelt av barna, for så å krysse av på skjemaet underveis eller rett etterpå. Intensjonen var sannsynligvis den aller beste: å skaffe seg et så godt og rettferdig grunnlag for halv- og helårsvurderingene som mulig. Ingen skulle kunne hevde at hun satte feil karakter, for hun hadde dokumentasjonen i orden. Kanskje tenkte hun at det også var en måte å se alle barna på. Både for å overleve og for å kunne skille barna fra hverandre, hadde hun laget seg dette sirlige vurderingssystemet, og det var på en av disse vurderingsrundene at Eleven hadde vært så uheldig å gjøre det hun fryktet var en skjebnesvanger feil.

Læreren kan imidlertid ikke uten videre klandres. Hun var en kjempeflink og engasjert lærer som elsket faget sitt. Men hun var satt til å virke innenfor et system som la opp til at lærere måtte forholde seg til fagene sine og elevene sine på det jeg velger å kalle fragmenterende og forkrøplende måter. Istedenfor å kunne bruke overskuddet, energien og kjærligheten til faget til å inspirere elevene og gi dem dyptgripende danningserfaringer, oppfordret systemet lærerne til å bruke overskuddet og energien på å tolke og operasjonalisere læreplanmål og gjennomføre vurderingsopplegg som dessverre tjente til å hemme heller enn å fremme lærelyst og indre liv. I eksemplet vårt hadde elevens lærer skapt et gjennomstrukturert og strømlinjeformet system for undervisning og vurdering i faget. Det var knapt plass igjen til spontane og ekte møter mellom Læreren og Eleven. Eleven opplevde at hun i Lærerens øyne var et elevobjekt i massen av andre elevobjekter, betraktet gjennom et vurderende øye snarere enn et elskende. Alle ble de, elevobjektene, vurdert ved hjelp av skjemaene som kategoriserte enkeltprestasjoner etter lærerfortolket måloppnåelse. Læreren var på mange måter blindet av læreplanverket og vurderingsforskriften. Det hadde skapt et slags tunnelsyn hos det ellers så engasjerte og dyktige fagmennesket. Således $\emptyset$ dela det ikke bare for Eleven og de andre barnas opplevelse av faget, men også for Læreren. Hun hadde langt på vei opphørt å være en selvstendig mat og helsepedagog, og isteden blitt en flittig og pliktoppfyllende funksjonær i et forkrøplende system. Dette, og her kommer hovedpoenget mitt i denne refleksjonen, har helse- og livsmestringsmessige konsekvenser både for lærere og elever. Hvordan?

\section{BEGREPENE《HELSE》 OG 《LIVSMESTRING》}

La oss begynne med kort å se nærmere på begrepene helse og livsmestring. Søker en på begrepet helse i Det norske akademis ordbok (se NOAB 2019), finner en at ordet stammer fra norrønt heilsa, som på den ene siden betyr sunnhet og kraft, og på den andre siden benevner et menneskes sunnhetstilstand eller konstitusjon. Ordet er beslektet både med hel og hell. Hel handler om det som er i sin opprinnelige eller riktige og normale skikk og form, og/eller det som er uten brist eller skade, og/eller det som ikke er oppdelt eller knust, men som (fort- 
satt) utgjør et sammenhengende hele. Hell handler om det å være heldig i livet, altså ha flaks, og det tilsvarer også det norrøne heill, som betyr lykke, varsel eller tegn. Søker en på begrepet livsmestring, er det imidlertid lite å finne annet enn oppføringen «det å mestre livet; det å få et harmonisk liv».

Går vi til eksemplet vårt, kan vi spørre hva en alltid vurderende måte å forholde seg til seg selv, fagene, kunnskapen og unge mennesker på, gjør med læreren og elevene over tid. Hva slags skolekultur skapes? Er det en kultur som fremmer god helse og evne til å mestre livet sitt, eller er det det motsatte? La meg med en gang og selvkritisk understreke at det selvfølgelig ikke finnes noe entydig og generelt svar på disse spørsmålene, da ulike lærere og ulike skolekulturer vil formes ulikt, blant annet avhengig av ledelseskulturene på nivåer over klasserommet. Jeg drister meg likevel til å påstå at eksemplet med Eleven og Læreren er symptomatisk for noen av de mest dominerende kulturelle strømningene som har vært formende på folk og strukturer i norsk skole de siste 30 årene. Strømningene fremmer jevnt over fragmentering framfor helhet og helse, prestasjonsorientering og frykt framfor harmoni og balanse i liv, selv om intensjonen godt kan være det motsatte.

I formålsparagrafen heter det for eksempel at «elevane og lorlingane skal utvikle kunnskap, dugleik og holdningar for å kunne meistre liva sine og for å kunne delta $i$ arbeid og fellesskap i samfunnet ». Dei skal få utfalde skaparglede, engasjement og utforskartrong. I og med at disse to setningene sees i sammenheng $\mathrm{i}$ dokumentet, kan de tolkes sammen: Skaperglede, engasjement og utforskertrang er en forutsetning for å kunne utvikle kunnskap og holdninger for å kunne mestre livene sine og delta i arbeid og fellesskap i samfunnet. I eksemplet vårt så vi hvordan det motsatte var i ferd med å skje. Barnet gikk inn i mat- og helsefaget med massevis av skaperglede, engasjement og utforskertrang når det gjaldt de delene av faget som handlet om matlaging og kakebakst. Imidlertid ble gleden over faget nær druknet av kulturmønstret som påla Læreren å bedrive intensiv elevvurdering og dokumentasjon. Hendelsen synliggjør mulige konsekvenser av overfokus på mål, kompetanse, ferdigheter og vurdering. I stedet for at mat- og helsetimene bidro til å fremme helse og livsmestring, hadde vurderingskulturen skapt en stressreaksjon som over tid er egnet til å svekke tenåringens generelle helse. Hen virket å være konstant oppmerksom og på vakt overfor Læreren, på godt og vondt: Ser hen meg nå? Er det jeg gjør bra nok? Skal man ha som ambisjon å «utvikle kunnskap, dugleik og holdningar for å kunne meistre liva sine», burde bildet imidlertid vært et annet. Da burde barnet kjent seg trygg nok til å kunne feile og lære av sine feil, og fri til å engasjere seg og utforske uten frykt for at hver ting hen gjorde skulle bli vurdert på en måte som fikk negative konsekvenser. Overvåkning gir sjelden grobunn for god vekst hos barn og unge. Snarere trenger de et åpent rom der de kan tenke, utforske og 
skape fritt, på en mest mulig lekende måte. Og for Lærerens del kunne mye vært annerledes hvis også hun hadde hatt frihet til å bruke sin egen skaperglede og sitt eget engasjement for faget inn i undervisningen, framfor å føle seg forpliktet til å ha fokus på læreplanmål og vurdering. Eleven og læreren var med andre ord begge fanget $i$ en dehumaniserende og fragmenterende kultur som hemmet heller enn fremmet ikke bare helse og livsmestring, men også flere andre av verdiene og prinsippene i formålsparagrafen, til tross for de beste intensjoner om det motsatte. Både læreren og eleven hadde mistet noe av sin sjel. For hvordan skal barn og unge utvikle solidaritet og evne til å bidra i et fellesskap dersom ikke klasserommets og skolens liv i seg selv fungerer som et genuint fellesskap? Det holder ikke å snakke om slike verdier, ei heller å la dem bare forbli ord i dokumenter som aldri leses. De må leves i det konkrete handlingsorienterte dagliglivet sammen med andre mennesker. Hvordan lærer man for eksempel barn og unge å bli tilgivende, respektfulle og solidariske? Hvordan lærer man dem å ta gode livsvalg? Kan det i det hele tatt læres bort, eller avhenger det primært av elevenes eget engasjement og vilje til å strebe etter å bli mer tilgivende, respektfulle og solidariske? Aller minst nytter det å gjøre slike verdier til mål som skal oppnås i instrumentell forstand. Da blir det fare på ferde. Å fremme slike verdier avhenger av et vekselvirkningsforhold mellom lærerens gode tilrettelegging og elevens egen innsats. Man kan lede hesten til kilden, men man kan ikke tvinge den til å drikke, heter det i ordtaket. På dette området vil rigid og overdreven vurderingspraksis ha potensiale for å virke svært $\emptyset$ deleggende. Kan vi håpe på bedre tider når det gjelder muligheten til å fremme helse og harmoniske liv både hos elever og lærere i årene som kommer?

\section{Mulighetsrom i Ny OVERordnet Del aV LereplanVerket?}

Med det som er sagt i det foregående, har jeg allerede antydet at jeg anlegger et litt annet perspektiv på temaet folkehelse og livsmestring enn det for eksempel Geir Skeie gjorde i den korte teksten «Livsmestring» i læreplanverket i Prismet 4/2017. «Folkehelse» knytter i hans forståelse forbindelsen til det medisinske systemet, mens «livsmestring» kan se ut til å referere til hele bredden i hvordan man håndterer livet og hverdagen. Jeg ser begge begrepene $\mathrm{i}$ et bredt perspektiv, og knytter dem begge til helhet, sammenheng og en harmonisk utvikling, i motsetning til fragmentering og en ubalansert utvikling. Som Skeie ser jeg en mulighet $i$ at beskrivelsen av temaet folkehelse og livmestring brukes om noe som nærmer seg det eksistensielle, og at ordene «religion» og «livssyn» knapt er nevnt utenom sitatene fra opplæringsloven. Dermed fristilles eksistensielle spørsmål og søken etter svar på disse fra religions- og livssynsfaget. De knyttes snarere til menneskers helse, livsmestring og velbefinnende i vid forstand. Skeie tolker det i forlengelsen av et forskningsprosjekt han ledet i Sverige. 
Faget «livskunskap» hadde dukket opp «nedenfra» som en betegnelse skolene selv brukte på en del av sin virksomhet som arbeidet med at elevene skulle ha det bedre både med seg selv og andre. Internasjonalt er dette ifølge Skeie inspirert av «life-skills»-tenkning og av tendenser som gjerne kalles «terapeutisk utdanning». Perspektivet er ikke ulikt det Ole Jacob Madsen har vært opptatt av fra et psykologisk perspektiv (Madsen 2017). Skeie og kollega Zetterquist har drøftet det de ser som tendenser til at religion og religiøsitet kan dukke opp på uventede steder i skolen, og likne på helsefremmende virksomhet (Zetterquist og Skeie 2014). Skeies spådom er at vi vil få økende tilbud til skolen fra både skolemedisinsk, psykologisk og alternativ medisinsk sektor begrunnet i deres potensiale for $\emptyset \mathrm{kt}$ livsmestring, og i og med åpningen som er skapt i og med ny overordnet del av læreplanverket.

Min bekymring er imidlertid at hvis alle disse tilbudene kommer som et supplement til en fortsatt rigid mål- og vurderingsorientert pedagogisk kultur, vil tilbudene paradoksalt nok kunne bidra til en ytterligere fragmentering av barns og unges liv, og dermed av skolekulturen spesielt og norsk kultur generelt. Det finnes imidlertid en annen vei å gå: i retning visdom. Hvordan? Ved å trekke på innsikter fra verdens gamle visdomstradisjoner.

Både i antikk og østlig filosofi og i jødisk-kristen og muslimsk tradisjon er visdom et kjernebegrep, og det er nært knyttet til det å leve et helsemessig sunt og moralsk godt liv. Ett eksempel er det latinske uttrykket «Mens sana in corpore sano». Det oversettes gjerne med «En sunn sjel i et sunt legeme», og peker på sammenhengen mellom kropp og sinn/sjel. Uttrykket kan med fordel brukes som et regulativt ideal for en helhetlig helse- og livsmestringsfremmende pedagogisk praksis i skolen. Selv var jeg allerede i 1991 prosjektleder for en helsekampanjeuke ved Universitet i Oslo - Helsiaden - der dette uttrykket var mottoet.

Også den mer enn 5000 år gamle indiske yogatradisjonen ser sinn og kropp i sammenheng. Vår del av verden har i det vesentlige og feilaktig splittet og fremmet to av dimensjonene i denne tradisjonen - de fysiske øvelsene (asanas) som vi møter på treningssentrene, og mindfulness-øvelsene, som ofte knyttes til terapi. Med det splittes ofte kropp og sjel i måtene yoga praktiseres på i vår del av verden. Men yoga betyr opprinnelig enhet eller helhet (unity), og i tradisjonell yoga holdes de to dimensjonene sammen. Det er en helhetlig og praktisk måte å leve livet på som involverer kroppen ved å legge vekt på sunn mat, fysisk aktivitet og praktisk bruk av pust, og sinnet ved å legge vekt på trening av disiplinert tenkning, følelsesliv og evne til konsentrasjon, samt integreringen av kropp og sinn i gode vaner og god handling. Yoga handler altså både om handling og væren, om aktivitet og fullstendig sinnsro, og representerer altså en tilnærming til helse og livsmestring som er langt videre og mer helhetlig enn det de fleste 
i vår del av verden antar. Yoga kan dermed også knyttes til den opprinnelige betydningen av helsebegrepet.

Også innsikter utviklet så vel i Kina på Lao Tzus eller Confusius` tid, i Hellas på Sokrates, Platon eller Aristoteles' tid, i India på Siddhartha Gautama Buddhas eller Gandhis tid, i Midtøsten på Jesu eller Muhammeds tid, kan være direkte aktuelle i en pedagogisk praksis som kan bidra til å fremme elevers og læreres helse og livsmestring i dag. Dette har jeg vist i boka «Philosophising the Dialogos way towards Wisdom in Education», som kommer på Routledge nå i vår (2019). I boka viser jeg hvordan Dialogostilnærmingen til pedagogisk filosofisk praksis kan brukes på tvers av skolens teoretiske fag, og styrke elevers og studenters visdom og livsmestring. Spørsmålet som har meldt seg for meg nå, er hvordan arbeidet i skolens praktiske og estetiske fag kan bidra til det samme, jamf $ø$ r eksemplet vårt som snarere illustrerer en helsehemmende praksis?

\section{ROM FOR HOLISTISKE UNDERVISNINGSPRAKSISER}

Ett foreløpig svar er at en holistisk undervisning rettet mot helse og livsmestring fordrer at undervisningen gjennomføres ved hjelp av varierte aktiviteter som bidrar til at elevene så ofte som mulig kan oppleve å komme inn i en helsebringende flyttilstand - denne lekende tilstanden der de blir ett med det de gjør og med hverandre, og der tiden opphører å eksistere for en stakket stund. Når elever erfarer å være i flyt, erfarer de både verden og seg selv som hele. Ulike elever vil sannsynligvis erfare flytopplevelser i ulike aktiviteter, avhengig av individuelle interesser og ferdigheter. Det kan skje gjennom så vel matlaging, fysisk bevegelse, lesing og tenkeskriving, tegning og maling, musikk, drama og andre kreative aktiviteter. Meditative og kontemplative $\emptyset$ velser i forkant av aktiviteter kan hjelpe dem å komme inn i slike helsebringende flyttilstander. Slike øvelser kan med fordel gis plass blant tradisjonelle metoder og arbeidsmåter. Selve aktivitetene er imidlertid bare én dimensjon ved helse- og livsmestringsfremmende pedagogiske praksiser. En annen dimensjon er innholdet, som ideelt og samlet sett bør gi næring til både kropp og sinn, og ikke bare fremme fragmenterende ferdigheter, kunnskaper og kompetanser. Det er således ikke likegyldig hva barn og unge leser eller bringes til å tenke på eller gjøre i skolen. Innholdet bør på ulike måter inspirere og gi næring til det indre livet deres. Det fordrer også at fokus i skolen må dreies fra vurdering og testing i retning av innhold og aktivitet. Skolens danningsoppdrag må med andre ord bringes i forgrunnen. Tradisjonelle pedagogiske begreper som moralsk, eksistensiell, estetisk og filosofisk innsikt og dannelse må igjen bli en del av læreres og skolelederes vokabular. 


\section{Avsluttende kommentar}

Det blir spennende å se om Læreren i eksemplet vårt med god samvittighet og vil kunne endre fokus $\mathrm{i}$ en mer helse- og livsmestringsfremmende retning $\mathrm{i}$ årene som kommer. Det blir også spennende å se om skolens øvrige praksiser vil utvikles slik at de faktisk bidrar til å fremme helse og livsmestring framfor fragmentering og disharmoni. Det fordrer imidlertid et gjennomgripende nybrottsarbeid der skolens danningsoppdrag løftes fram og får danne forgrunnen, og der man hele tiden har tilrettelegging for elevenes helhetlige og harmoniske utvikling for $\emptyset$ ye. Barn og unge er ikke primært innsatsfaktorer i statens politikk for fortsatt $\emptyset$ konomisk vekst. De er mennesker med sitt eget indre liv og egne mål for tiden de har fått her på jorden.

\section{LITTERATUR}

Gibran, Khalil. 1994/1923. Profeten. Oslo: Gyldendal norsk forlag.

Helskog, Guro Hansen. 2019. Philosophising the Dialogos way toward wisdom in Education. Between Critical Thinking and Spiritual Contemplation. London: Routledge Publishing LTD

Helskog, Guro Hansen. 2011. «Danning gjennom filosofisk dialog. En mulighet i det flerkulturelle og flerreligiøse samfunnet?» I: Hagtvedt, Bernt og Gorana Orgnjenovic: Dannelse. Tenkning, modning, refleksjon. Oslo: Dreyer forlag.

Helskog, Guro Hansen og Ribe, Andreas. 2009. Dialogos. Veiledning for løere og samtaleledere. Bergen: Fagbokforlaget.

Madsen, Ole Jacob. 2017. Den terapeutiske kultur. Oslo: Universitetsforlaget

NAOB - Det Norske Akademis ordbok. Lastet ned den 20.01.2019 fra https://www.naob. no/ordbok/helse_2

Skeie, Geir. 1917. «'Livsmestring» i læreplanverket.' I: Ny overordnet del av læreplanen for skolen» I Prismet - IKO-Forlaget 2017: 4 S. 327-337 